\title{
Evaluation of chimeric proteins for serological diagnosis of brucellosis in cattle
}

\author{
Aitbay K. Bulashev1 ${ }^{1}$, Bakytkali K. Ingirbay ${ }^{1}$, Kanatbek N. Mukantayev²(D) and Alfiya S. Syzdykova1 ${ }^{1}$ (D) \\ 1. Department of Microbiology and Biotechnology, Faculty of Veterinary and Livestock Technology, S. Seifullin \\ Kazakh Agrotechnical University, Nur-Sultan, 010011, Kazakhstan; 2. Laboratory of Immunochemistry and \\ Immunobiotechnology, National Center for Biotechnology, Nur-Sultan, 010000, Kazakhstan. \\ Corresponding author: Aitbay K. Bulashev, e-mail: aytbay57@mail.ru \\ Co-authors: BKI: bakytkali.kabi@mail.ru, KNM: mukantaev@biocenter.kz, ASS: halik.kz@mail.ru \\ Received: 20-04-2021, Accepted: 14-07-2021, Published online: 24-08-2021
}

doi: www.doi.org/10.14202/vetworld.2021.2187-2196 How to cite this article: Bulashev AK, Ingirbay BK, Mukantayev KN, Syzdykova AS (2021) Evaluation of chimeric proteins for serological diagnosis of brucellosis in cattle, Veterinary World, 14(8): 2187-2196.

\begin{abstract}
Background and Aim: An accurate diagnosis of Brucella-infected animals is one of the critical measures in eradication programs. Conventional serological tests based on whole-cell (WC) antigens and detecting antibodies against pathogenassociated lipopolysaccharide might give false-positive results due to the cross-reactivity with other closely related bacteria. This study evaluated the serological potential of Brucella spp. chimeric outer membrane proteins (Omps) as antigens in an indirect enzyme-linked immunosorbent assay (i-ELISA).

Materials and Methods: The chimeric gene constructs of the most immunodominant regions of Brucella Omps 25+31, $25+19$, and 19+31 were cloned into the pET28a expression vectors and transformed into Escherichia coli BL21 (DE3). The serological potential of chimeric proteins compared with single recombinant Omps (rOmps)19, 25, and/or 31 were studied on blood serum samples of (i) a rabbit immunized with killed Brucella abortus 19WC, (ii) mice immunized with single rOmps, (iii) cows seropositive for brucellosis by rose Bengal test, and (iv) cattle naturally and/or experimentally infected with brucellosis.

Results: E. coli BL21 actively produced Brucella chimeric rOmps, the concentration of which reached a maximum level at $6 \mathrm{~h}$ after isopropyl- $\beta$-D-1-thiogalactopyranoside stimulation. Target proteins were antigenic and expressed in an active state, as recognized by rabbit anti- $B$. abortus antibodies in an i-ELISA and western blotting. Murine antibodies against the single rOmps reacted with chimeric antigens, and conversely, antichimeric antibodies found their epitopes in single proteins. Brucella chimeric rOmps showed higher antigenicity in blood sera of seropositive cattle kept in the hotbed of the infection and/or experimentally challenged with brucellosis than single proteins.
\end{abstract}

Conclusion: Brucella chimeric recombinant outer membrane proteins could be a potential antigen candidate for developing an ELISA test for accurate diagnosis of bovine brucellosis.

Keywords: Brucella, chimeric protein, enzyme-linked immunosorbent assay, serological potential.

\section{Introduction}

Brucellosis is one of the most widespread zoonosis globally that significantly reduces livestock productivity and possesses a danger to human health. It remains endemic in some countries of the Middle East, Africa, South and Central America [1], South [2], and Central Asia, including the Republic of Kazakhstan (RK) [3]. A prompt and accurate diagnosis of infected animals is a critical element in the fight against brucellosis. The rose Bengal test (RBT), agglutination test (AT), and complement fixation test (CFT) are used for diagnosing bovine brucellosis in RK. Commercial enzyme-linked immunosorbent assay (ELISA) kits

Copyright: Bulashev, et al. Open Access. This article is distributed under the terms of the Creative Commons Attribution 4.0 International License (http://creativecommons.org/licenses/ by/4.0/), which permits unrestricted use, distribution, and reproduction in any medium, provided you give appropriate credit to the original author(s) and the source, provide a link to the Creative Commons license, and indicate if changes were made. The Creative Commons Public Domain Dedication waiver (http:// creativecommons.org/publicdomain/zero/1.0/) applies to the data made available in this article, unless otherwise stated. based on smooth Brucella lipopolysaccharide (S-LPS) were also used in the serological diagnosis of bovine brucellosis in the period from 2008 to 2013, when vaccination was canceled and "test and slaughter" was declared as the main method for combating brucellosis. The number of cattle positive for brucellosis by ELISA, a year after its introduction into practice, increased by an average of 7.3 times, but the epidemic situation remained tense [4]. These data suggest that large numbers of healthy cattle have been mistakenly identified as infected due to antibodies against S-LPS of bacteria closely related to Brucella spp. [5].

Among the nonpolysaccharide, Brucella cell components that can minimize cross-reactions are proteins [6], including outer membrane proteins (Omps). Early studies have shown that native proteins [7] and non-LPS antigens [8] can be used to solve cross-reactivity problems and differentiate infected from vaccinated cattle. Advances in genetic engineering have also eliminated difficulties in antigen preparation and the biohazard risks associated 
with cell culture and opened up new prospects for the study of Brucella recombinant Omps (rOmps) diagnostic value. It was found that the use of a single rOmp31 [9,10], rOmp28 [11], rOmp25, and/or rOmp31 [12] provides the specificity for indirect ELISA (i-ELISA) but significantly reduces its sensitivity. The combined use of Brucella rOmps10, 19, and 28 imparted a higher sensitivity to the assay in testing AT-positive blood serum samples [13]. The i-ELISA based on a combination of rOmps 25,28 , and 31 could even differentiate mice antibodies to virulent $B$. melitensis from antivaccine and/or nonspecific as well as cross-reactive ones [14]. However, these encouraging results have not been confirmed in productive animals. Previous studies showed that antibodies specific to rOmps19, 25, and 31 could also be found in more than half of the animals maintained in a brucellosis-free herd for as long as 10 months after revaccination with Brucella abortus 19 [15]. The use of i-ELISAs that detect Brucella anti-rOmps separately reduced the sensitivity of the test. These findings led us to speculate that a combination of the rOmps could be a reliable antigen for developing an ELISA test to identify infected heifers before initial vaccination better. Thus, a chimeric (fusion) antigen comprising the most diagnostically important regions of several proteins and synthesized by a single producer strain would provide high accuracy for the analysis and the relative cheapness of a diagnostic kit.

This study was designed to obtain Brucella chimeric rOmps that might be used as an effective antigen for serological diagnosis of bovine brucellosis.

\section{Materials and Methods}

\section{Ethical approval}

All activities involving animals were approved by the Animal Ethics Committee, Faculty of Veterinary and Livestock Technology, S. Seifullin Kazakh Agrotechnical University (KazATU), and performed in accordance with the Guidelines for Accommodation and Care of Animals: Species-specific provisions for laboratory rodents and rabbits (Interstate Standard, GOST 33216-2014).

\section{Study period and location}

The study was conducted from March to December 2020. Sixty outbred male mice (9-10 weeks, 20-25 g body weight) were maintained under appropriate hygienic conditions in the vivarium of KazATU, Nur-Sultan, Kazakhstan.

\section{Bacterial strains, plasmids, and culture media}

The strains Escherichia coli DH5 $\alpha$ and BL21 (DE3) (Novagen, USA) and the plasmids pGEMTEasy (Promega, Medison, USA) and pET28 (Novagen) were used in this study. The cell cultures were grown on Luria-Bertani (LB) broth and LB agar media (Thermo Fisher Scientific, Waltham, USA) with ampicillin and/or kanamycin $(100$ and $50 \mu \mathrm{g} / \mathrm{mL}$, respectively) (Sintez, Kurgan, Russia).

\section{Design of genetic constructs}

On the basis of studies by Tibor et al. [16], Wergifosse et al. [17], and Vizcaino et al. [18], the most immunodominant regions of the Brucella spp. Omps19, 25, and 31 were selected, respectively. The search for the amino acid sequences of the selected proteins fragments was conducted using the NCBI PubMed databases (http://www.ncbi.nlm.nih.gov/ pubmed). Bioinformatic analysis was conducted using the Vector NTI v.11.5 software package (Invitrogen, USA). Codon optimization of the nucleic acid sequences for the E. coli $\mathrm{K} 12$ expression system was performed for the efficient expression of recombinant proteins. Based on the nucleotide sequences of the genes, three chimeric genetic constructs were created that are responsible for the synthesis of Brucella spp. fusion proteins in the following combinations: Omp19 +25 , Omp $19+31$, and Omp25 + 31 .

\section{Gene synthesis}

The chimeric genes of Brucella Omps selected fragments were synthesized by Macrogen (Seoul, South Korea) and obtained in lyophilized form with a concentration of $50 \mathrm{ng} / \mu \mathrm{L}$. Each gene contained restriction sites and six histidine codons (6His-tag) at 5 '-end.

\section{Cloning, expression, and purification of the chimeric recombinant proteins}

$E$. coli $\mathrm{DH} 5 \alpha$ was transformed with each of the three genes to generate a preparative amount of DNA and determine their nucleotide sequences. The bacterial cells grown on LB agar were analyzed using a polymerase chain reaction (PCR) using Taq polymerase (Thermo Fisher Scientific) and M13 primers (Promega, Medison, USA). The positive clones were used for DNA purification and sequencing. The BigDye Terminator reagent kit (Thermo Fisher Scientific) was used for sequencing. The resulting genes were cloned into the pET28 plasmid using the EcoRI and XhoI restriction sites.

BL21 (DE3) competent E. coli was transformed with the gene inserted plasmid vector $\mathrm{pET}-28$ by electroporation using a MicroPulser (Bio-Rad, USA) under the following conditions: $100 \mathrm{ng}$ of plasmid per $50 \mu \mathrm{L}$ cell suspension at $2.5 \mathrm{kV}, 25 \mu \mathrm{F}$, and $200 \mathrm{ohms}$. The duration of the electroporation was $5.0 \mathrm{~ms}$. The transformed cells were incubated in $950 \mu \mathrm{L}$ superoptimal broth (Thermo Fisher Scientific, Vilnius, Lithuania) at $37^{\circ} \mathrm{C}$ for $1 \mathrm{~h}$ with shaking at $150 \mathrm{rpm}$. Then, $50 \mu \mathrm{L}$ cells were plated on LB agar containing kanamycin as a selective antibiotic and grown at $37^{\circ} \mathrm{C}$ for $16 \mathrm{~h}$. Single colonies of transformants were cultured in LB broth with kanamycin. In the middle of the logarithmic phase of bacterial growth (absorbance at $\lambda=600 \mathrm{~nm}$, OD600=0.6), $0.1 \mathrm{mM}$ inducer, isopropyl- $\beta$-D-1-thiogalactopyranoside (IPTG) (Sigma-Aldrich, St. Louis, USA), was added, and the culture was incubated at room temperature for $16 \mathrm{~h}$ with shaking. Bacterial cells were collected by centrifugation at $6000 \times g, 4^{\circ} \mathrm{C}, 7 \mathrm{~min}$. 
Lysis of bacterial cells and chromatographic purification of target proteins

Bacterial cells were lysed using OmniRuptor 4000 Ultrasonic Homogenizer (Omni International, Georgia, USA) at $24 \mathrm{kHz}$ in a pulsed mode (10 pulses per second) in ice-cold buffer $(20 \mathrm{mM} \mathrm{NaCl}, 20 \mathrm{mM}$ HEPES, and 0.1 mM phenylmethylsulfonyl fluoride, $\mathrm{pH}$ 7.5). Recombinant proteins were purified by metal chelate chromatography $(\mathrm{Ni} 2+)$ on a $1 \mathrm{~mL}$ HisTrapTM HP column (GE Healthcare, USA). For this, inclusion bodies containing the recombinant proteins were harvested by centrifugation, and the supernatant was removed. The residue was dissolved in buffer $(20 \mathrm{mM}$ Tris-HCl, $\mathrm{pH}$ 8.0, containing $8 \mathrm{M}$ urea, $500 \mathrm{mM}$ $\mathrm{NaCl}$ ) and resonated. Insoluble material was pelleted by centrifugation and discarded. The protein solution was loaded onto a nickel-nitrilotriacetic acid column (bed volume $2 \mathrm{~mL}$ ) and equilibrated with the same buffer. The column was washed with ten volumes of equilibration buffer $(20 \mathrm{mM}$ Tris- $\mathrm{HCl}, \mathrm{pH} 8.0$, containing $8 \mathrm{M}$ urea; $500 \mathrm{mM} \mathrm{NaCl} ; 20 \mathrm{mM}$ imidazole). A linear imidazole gradient $(20-500 \mathrm{mM})$ was used for the final elution of the recombinant proteins from the chromatographic column. Fast protein liquid chromatography was used for protein purification. Protein fractions were detected at $\lambda=280 \mathrm{~nm}$. The target proteins were confirmed by western blot using anti-His Tag mouse monoclonal antibody (MAb) conjugated with horseradish peroxidase (HRP, Thermo Fisher Scientific).

\section{Sodium dodecyl sulfate-polyacrylamide gel electrophoresis (SDS-PAGE) and western blot}

The purified rOmps19+25, 19+31, and/or 25+31 were run on $12 \%$ SDS-PAGE gel. After electrophoresis, samples were transferred to nitrocellulose membrane (GE Healthcare Life Sciences, UK) at $2 \mathrm{~mA} /$ $\mathrm{cm}^{2}$ constant current for 60 min using a semidry electro blot(C) containing the transfer buffer (25 mM Tris$\mathrm{HCl}, 192 \mathrm{mM}$ glycine, and 20\% methanol). The membrane was blocked with $1 \%$ bovine serum albumin (Sigma-Aldrich, St. Louis, MO, USA) for $1 \mathrm{~h}$ at $4^{\circ} \mathrm{C}$, washed thrice with $0.05 \%$ phosphate-buffered saline (PBS), Tween-20 (PBS-T), and incubated with diluted rabbit anti-B. abortus $19 \mathrm{WC}$ serum (1:100) for $2 \mathrm{~h}$ at $4^{\circ} \mathrm{C}$. The membrane was washed with $0.05 \%$ PBS-T, incubated with HRP-labeled goat anti-rabbit antibodies (Jackson ImmunoResearch, West Grove, USA) for $1 \mathrm{~h}$ at $4^{\circ} \mathrm{C}$, and washed with $0.05 \%$ PBS-T. The proteins were developed in a 4-chloro-1-napthol solution (Sigma-Aldrich, St. Louis, USA).

Brucella rOmp19 [19], rOmp25, and rOmp31 [20] obtained in our previous research were used as single proteins for a comparative study of chimeric proteins' serological potential.

\section{Serum samples}

A total of 166 cattle sera were tested. Of these, 77 serum samples were from cows seropositive for brucellosis by RBT from a new infection focus
(Zhitikara rayon, Kostanay oblast, RK), 34 brucellosis-positive sera were obtained from the National Reference Center for Veterinary Medicine, Ministry of Agriculture, RK, and 12 serum samples were from cattle experimentally infected with the virulent strain $B$. abortus 544; this was kindly provided by Professor K. Tabynov, Head of the Laboratory for the Prevention of Infectious Diseases, Research Institute for Biological Safety Problems, RK. Forty-three sera were obtained from unvaccinated seronegative cattle by RBT, AT, and CFT (Bukhar-Zhyrau rayon, Karaganda oblast, RK) kept in a brucellosis-free farm was used as control samples.

Rabbit anti-B. abortus 19 whole-cell (WC) serum obtained in our previous study was used [15]. Mice anti-Brucella chimeric Omps sera were obtained as follows. Three groups of outbred mice, with 10 mice per group, were immunized twice subcutaneously with $25 \mu \mathrm{g}$ rOmp19+25, rOmp19+31, and/or rOmp25+31, respectively. Incomplete Freund's adjuvant (IFA) (Sigma-Aldrich, Taufkirchen, Germany) on day 0 and PBS (pH 7.2-7.4) on day 14 were mixed in equal amounts with immunogens. Blood was sampled from the tail vein on day 28; sera isolated after centrifugation were used to determine antibody titer against the used immunogens as well as individual (single) proteins (rOmps19, 25, and/or 31) using i-ELISA. As a negative group, ten mice without any injection were regarded.

Three groups of five outbred mice each were used to get mice anti-Brucella single rOmps sera. The mice were immunized with $25 \mu \mathrm{g}$ of the following proteins: rOmp19 (Group I), rOmp25 (Group II), and rOmp31 (Group III) according to the scheme described above. As a negative group, five mice without any injection were used.

Determination of the antigenicity of the chimeric proteins by i-ELISA using anti-Brucella WC sera

The wells in polystyrene plates (Thermo Fisher Scientific) were coated with rOmp $19+25$, rOmp 19 +31 , and rOmp25 + 31 at $1.0 \mu \mathrm{g} / \mathrm{mL}$ in bicarbonate buffer, $\mathrm{pH} 9.6$, and incubated at $4^{\circ} \mathrm{C}$ overnight. Rabbit antiserum to B. abortus $19 \mathrm{WC}$ and/or serum samples of cattle positive to brucellosis and/or experimentally infected with $B$. abortus 544 were diluted in eight protein-coated wells, starting with 1:100 in PBS-T; the plate was maintained at $37^{\circ} \mathrm{C}$ for $1 \mathrm{~h}$. Goat anti-rabbit immunoglobulin $\mathrm{G}$ ( $\mathrm{IgG})$-peroxidase (Jackson ImmunoResearch, West Grove, USA) and/ or rabbit antibovine antibodies (Sigma-Aldrich, St. Louis, USA) were used as secondary antibodies. The dilution of the antiserum was taken to determine the titer of the rabbit antibodies, the optical density (OD) of which was two or more times higher than the OD of the negative control serum at a dilution of 1:100. The cutoff value of i-ELISA for cattle was set at twice the average OD (492 nm) value of B. abortus-negative sera $(n=43)$ at a 200 -fold dilution [21]. 
Determination of the antigenicity of the chimeric proteins via i-ELISA using anti-Brucella single rOmps sera

The polystyrene plate wells were coated with chimeric proteins, and mice anti-rOmps 19, 25, and 31 sera were diluted as described above. In addition, antibodies bound to the plate were detected with HRPconjugated rabbit anti-mouse IgG (Sigma-Aldrich, St. Louis, MO, USA). The cutoff value for the assay was calculated as the mean-specific OD plus three standard deviations (SDs) for five sera from nonimmunized mice assayed at a 1:100 dilution.

Determination of the antigenicity of the single rOmps by i-ELISA using anti-Brucella chimeric Omps sera

Briefly, the wells of a polystyrene plate were coated with rOmps19, 25, and/or 31, and mice antisera against chimeric rOmps were diluted in wells coated with homologous single Omps as described above. The cutoff value for the assay was calculated as the mean-specific OD plus three SDs for 10 sera from nonimmunized mice assayed at a 1:100 dilution. All assays were conducted in triplicate and repeated thrice.

\section{Statistical analysis}

Comparisons between the OD mean values were analyzed using Student's t-test. Statistical analysis of antibody titers was conducted according to a previously described method [22]. Statistical significance was assumed at the $\mathrm{p}<0.05$ level.

\section{Results}

The amino acid sequences of the selected immunodominant regions of Brucella Omps19, 25, and 31 were as follows (Table-1). The restriction of the DNA inserts encoding the following three fusion proteins: Omp19+25, Omp19+31, and Omp25+31, and subsequent electrophoretic analysis revealed DNA bands with the expected sizes of 806, 734, and $653 \mathrm{bp}$, respectively (Figure-1). The resulting DNA fragments were purified from the gel, ligated to the expression vectors, and transformed into the E. coli BL21 (DE3) cells. Bacterial cells were grown on LB broth, and the addition of IPTG induced the expression of the chimeric proteins. SDS-PAGE data of cell lysates are shown in Figure-2. As shown in Figure-2, $6 \mathrm{~h}$ of post-induction incubation was optimal to produce target proteins with higher volumetric yield.

An electrophoretogram and western blot of Brucella chimeric rOmps purified by metal chelate chromatography $(\mathrm{Ni2}+)$ are given in Figure-3. The target proteins have an apparent molecular weight of 35,32 , and $27 \mathrm{kDa}$ for rOmps $19+25,19+31$, and $25+31$ by electrophoresis, respectively. The specificity of the obtained proteins for Brucella spp. was confirmed by the results of immunoblot analysis using hyperimmune serum obtained on day 45 from a rabbit by immunization with phenol-killed B. abortus $19 \mathrm{WC}$.

The same rabbit antiserum was used to study the comparative antigenicity of Brucella chimeric and/or 
individual proteins (Table-2). Anti-rOmp19+31 and anti-rOmp25+31 antibodies in the blood serum of a rabbit hyperimmunized with inactivated bacterial cells were detected up to a serum dilution of 1:12,800, whereas the antibodies titer against rOmp19+25 and single recombinant proteins (rOmps19 and/or 25) did not exceed 1:1,600. These data indicated that used fusion rOmps were expressed in E. coli BL21 in an active form. The expression of chimeric proteins was also confirmed by western blot using His Tag MAb (data not shown).

Chimeric proteins showed sufficient immunogenicity since in the blood sera of mice taken on day 28 after double injections of immunogens suspended in IFA and then in PBS, antibodies against rOmps $19+25,19+31$, and/or $25+31$ were detected up to titers $1: 3,940(+32.0 \% ;-24.2 \%), 1: 1,840(+52.6 \%$; $-34.4 \%)$ and $1: 1,040(+65.9 \% ;-39.7 \%)$, respectively. Note that the immunogenicity of rOmp19+25 was significantly higher than that of rOmp $19+31(\mathrm{p}<0.05)$ and rOmp25+31 $(\mathrm{p}<0.01)$. These mice antichimeric sera were used to study the antigenicity of Brucella single rOmps by i-ELISA (Figure-4).

Antibodies against fusion proteins showed activity against Brucella rOmps19, 25, and/or 31, and their titers depend on the type of antiserum and antigen, ranged from $1: 170$ to $1: 800(+24.0 \% ;-19.7 \%)$. AntirOmp19+25 antibody was more immunoreactive to homologous single proteins (rOmp19 and rOmp25), than the other two antichimeric antibodies, detecting

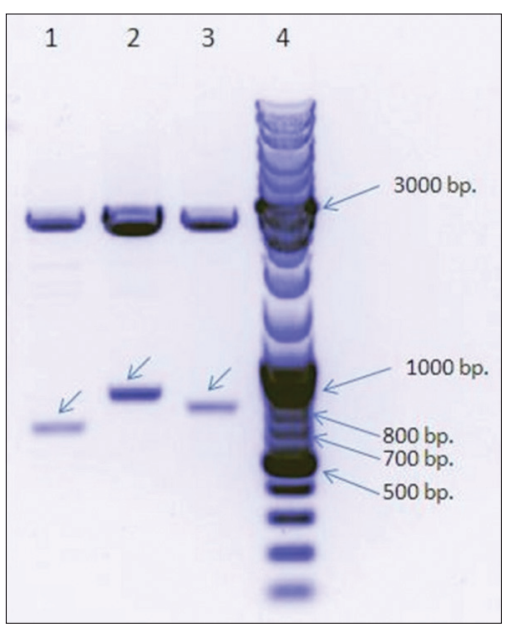

Figure-1: Restriction fragments of Brucella chimeric outer membrane proteins genes and pUC57 vector. (1) Omp25+31 (653 bp.); (2) Omp19+25 (806 bp.); (3) Omp19+31 (734 bp.); (4) markers. them up to a serum dilution of $1: 800(+24.0 \% ;-19.7 \%)$ and 1: $610(+15.7 \% ;-13.5 \%)$, respectively $(\mathrm{p}<0.05)$.

Brucella spp. chimeric proteins were recognized by mice antibodies raised against individual rOmps (Table-3). Fragments of the single rOmps used to create fusion proteins retain their antigenicity, as evidenced by antibodies' binding against the whole single proteins to chimeric antigens. There was no statistically significant difference between the antibody titers of the sera used, and only anti-rOmp31 serum showed higher titers $(1: 740 ; \mathrm{p}<0.05)$ to the homologous protein in the structure of rOmp19+31 fusion antigen. The sensitivity, specificity, and accuracy of the rOmps based i-ELISA compared with the RBT are presented in Table-4.

ELISA based on chimeric proteins showed maximum sensitivity with a specificity of $95.3-100 \%$ and accuracy of $97.4-100 \%$, whereas these indicators, when using the single rOmps were in the range of 88.2$97.1 \%, 79.1-93.0 \%$, and $72.7-87.0 \%$, respectively. Judging by the mean ODt/ODc values, rOmp19+31 binds to specific antibodies more strongly than rOmp19+25 $(\mathrm{p}<0.05)$ and rOmp25+31 $(\mathrm{p}<0.01)$. The serological potential of Brucella spp. rOmps was studied on 89 cattle sera, including 77 and 12 Brucellapositive samples of cows naturally and experimentally infected with brucellosis, respectively (Table-5).

The antigenicity of Brucella spp. rOmp19+31 (94.8\%) and rOmp25+31 (98.7\%) in blood sera of cows kept in the hotbed of a new brucellosis infection was significantly higher compared to rOmp19+25 and individual proteins. Simultaneously, the mean ODt/ODc values in anti-ELISA/rOmp19+31 greatly exceeded those when both single and other chimeric proteins were used in the test $(p<0.01)$. Antibodies against fusion rOmps and/or rOmp19 were detected in serum samples of all experimentally infected animals (on day 14 post-infection); however, ELISA based on rOmp25 and/or rOmp31 showed positive results only in $66.7 \%$ and/or $58.3 \%$, respectively.

\section{Discussion}

Despite the importance of brucellosis for veterinary medicine and public health, serological tests developed at the beginning (AT and CFT) and/or in the second half of the last century (RBT, etc.) remain the main diagnostic methods this day. Highly sensitive immunological methods based on the use of labeled antigens and/or antibodies, such as ELISA and lateral

Table-2: Antigenicity of Brucella spp. rOmps in rabbit anti-B. abortus $19 W C$ serum.

\begin{tabular}{|c|c|c|c|c|c|}
\hline \multicolumn{6}{|c|}{ Brucella spp. rOmps used as antigens in an indirect enzyme-linked immunosorbent assay } \\
\hline \multicolumn{3}{|c|}{ Individual recombinant proteins } & \multicolumn{3}{|c|}{ Chimeric recombinant proteins } \\
\hline rOmp19 & rOmp25 & rOmp31 & rOmp19+25 & rOmp19+31 & rOmp25+31 \\
\hline \multicolumn{6}{|c|}{ Titers of anti-B. abortus $19 W C$ antibody } \\
\hline $1: 1,600$ & $1: 1,600$ & $1: 6,400$ & $1: 1,600$ & $1: 12,800$ & $1: 12,800$ \\
\hline
\end{tabular}




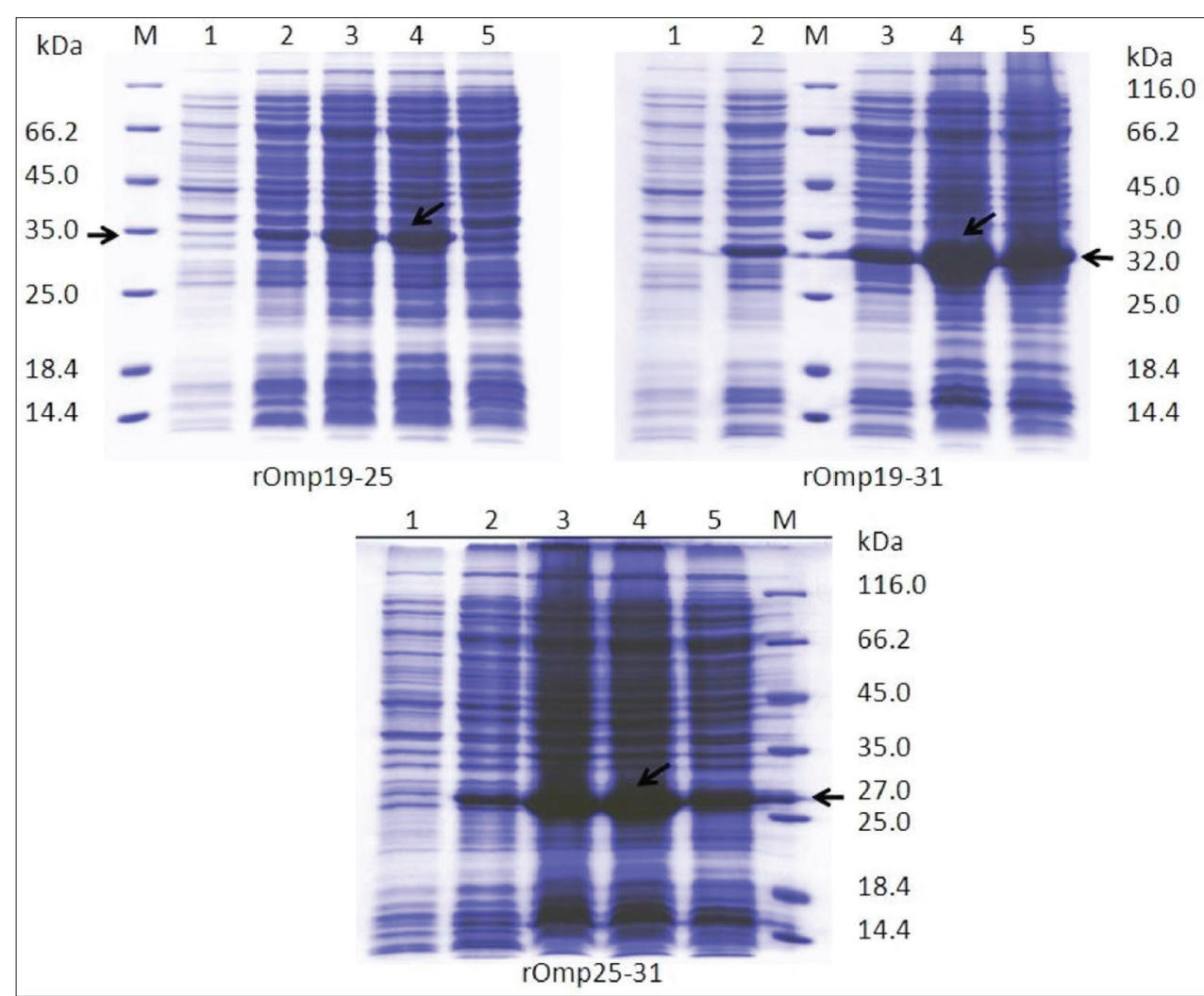

Figure-2: Sulfate-polyacrylamide gel electrophoresis analysis of Brucella chimeric recombinant outer membrane proteins. (1) Before IPTG-induction; (2) $2 \mathrm{~h}$ after IPTG-induction; (3) $4 \mathrm{~h}$ after IPTG-induction; (4) $6 \mathrm{~h}$ after IPTG-induction; (5) after overnight induction; $\mathrm{M}=$ Markers.

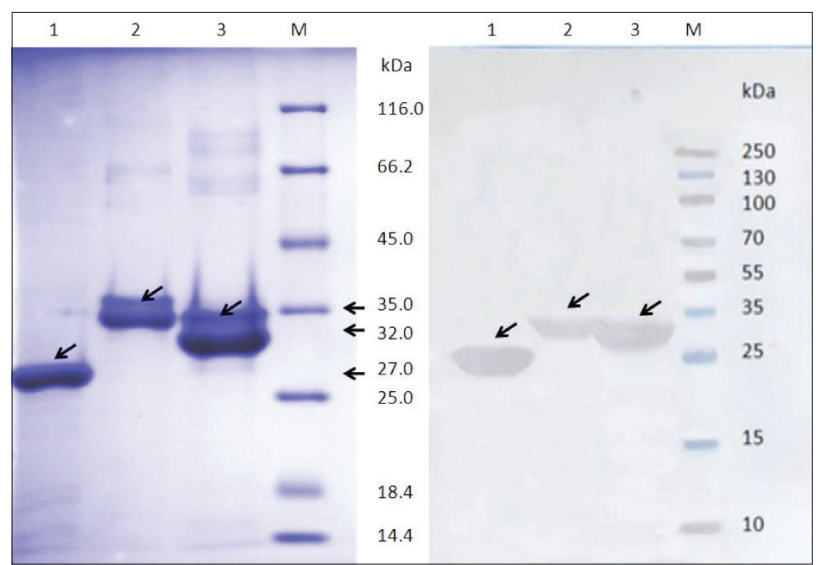

Figure-3: Sulfate-polyacrylamide gel electrophoresis (SDS-PAGE) analysis of chimeric recombinant outer membrane proteins (rOmps) produced by Escherichia coli BL21 (a) and antigenicity of the expressed proteins by western blot (b). The proteins were separated by $12 \%$ SDS-PAGE and stained with Bromophenol blue R250 (a). The antigenicity of the proteins was elucidated with rabbit anti-Brucella abortus 19WC serum with a titer 1: 51200 by indirect enzyme-linked immunosorbent assay (b). The arrows indicate chimeric rOmps. Lane 1: rOmp25+31; Lane 2: rOmp19+25; Lane 3: rOmp19+31; Lane M=Markers.

flow assay, are now being introduced into the practice of diagnosing brucellosis. The main obstacle to the widespread use of modern tests is the lack of serologically potential antigens specific to Brucella spp. Like traditional serological tests, ELISA kits available on the veterinary market are based on the use of pathogen's S-LPS, which could lead to false-positive results due to antigen cross-reactivity. The search for specific antigens is the key to increasing the diagnostic accuracy of serological tests. Among non-LPS antigens, Omps have been characterized as potential immunoreactive antigens for diagnosis of bovine [12,23,24], ovine, caprine [25], and human brucellosis [26]. Brucella spp. Omps, unlike LPS, could (i) differentiate specific antibodies from cross-reactive ones [27], (ii) be produced from harmless producer strains, (iii) have stable antigenic properties, and (iv) improve assay standardization [28]. Brucella Omps certainly provide specificity for serological tests but using a single protein reduces ELISA sensitivity $[12,29]$. This might be related to the fact that all antibodies could not detect a single protein within the overall population. In a study, we found that testing cattle blood sera for antibodies to single proteins (Omp19, Omp25, and/or Omp31) does not identify all seropositive animals. Moreover, antibodies to Omps were detected not only in the infected but also in a particular part of vaccinated animals for a long time after immunization $[12,15]$. Thus, Omps could only be used to identify infected animals in an unvaccinated herd. Other researchers share our opinion, who argue that the presence of anti-Brucella antibodies in unvaccinated animals is always suggestive of infection [30]. Thus, we believe that recombinant antigens comprising several proteins should be used for the reliable detection of infected cattle among non-immune livestock. The main drawback of this 
approach is the high cost of serological testing, since it will be necessary to have several producer strains and work on the production and purification of two or more recombinant proteins. In addition, each single protein that makes up the combined antigen might have weakly antigenic and/or cross-reacting fragments as well as compete with each other for binding to the ELISA solid phase.

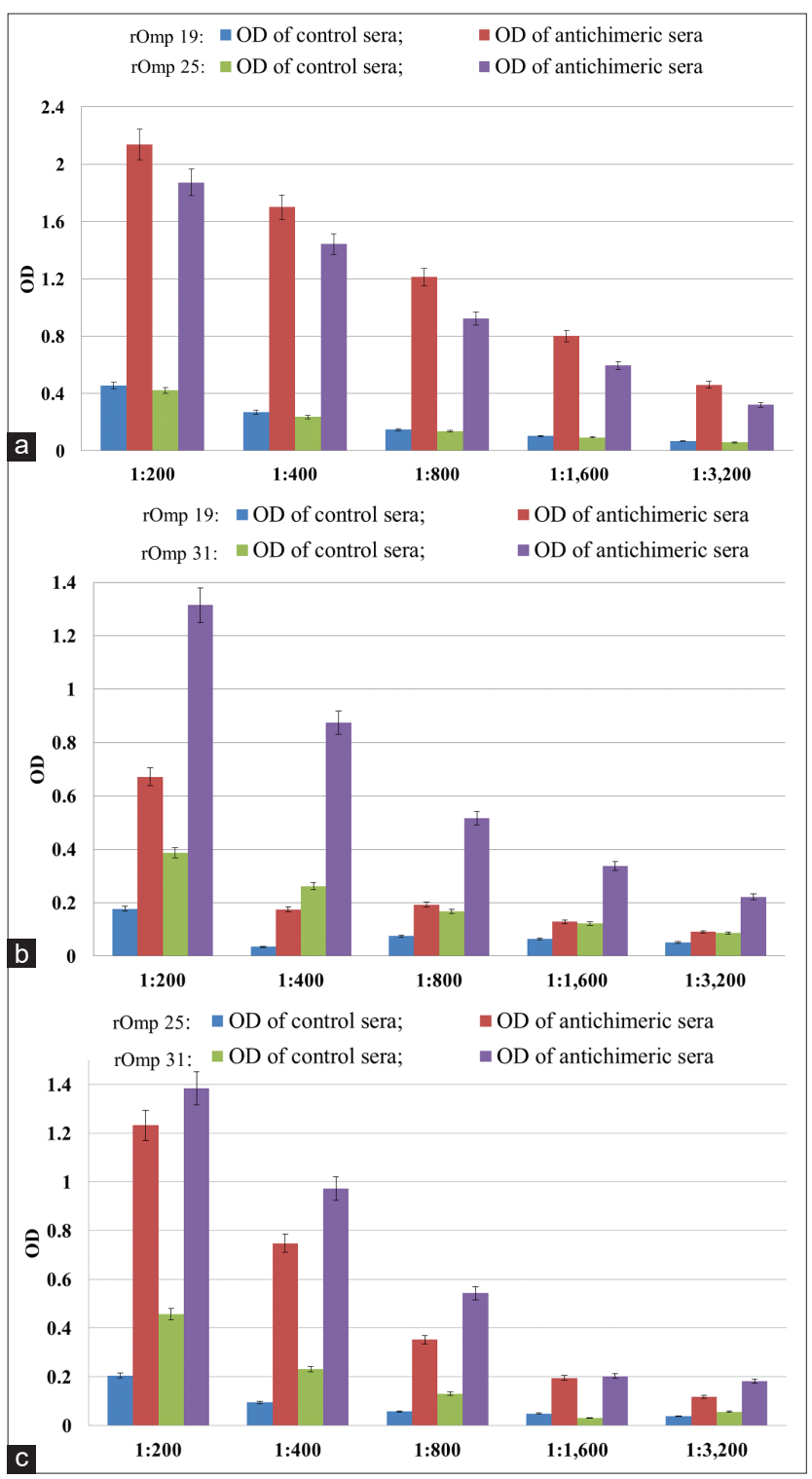

Figure-4: Antigenicity of Brucella single recombinant outer membrane proteins (rOmps) in mice anti-chimeric proteins sera yielded day 28 . The results of indirect enzyme-linked immunosorbent assay based on rOmps19, 25 and/or 31 are showed in detail. (a) rOmp19 and rOmp25, (b) rOmp19 and rOmp31, and (c) rOmp 25 and rOmp 31.
In this study, three types of antigen, each comprising the immunodominant regions of two Brucella Omps, were successfully expressed in E. coli BL21 (DE3) cells using the pET28 plasmids and their efficacy was assessed in an attempt to increase the sensitivity of the i-ELISA for serological diagnosis of bovine brucellosis. These chimeric proteins, designated rOmp $19+25$, rOmp $19+31$, and rOmp 25 +31 were composed of active serological parts of Brucella spp. Omps 19, 25, and 31. The recombinant proteins differ from the native ones and may lose some function after expression and/or purification. Besides, western blot procedures might impact their structure. It is impossible not to consider the fact that the immunoreactivity of proteins might be different when comparing in vitro to in vivo conditions [28]. Thus, the purified chimeric proteins were subjected to relevant studies to verify their validity. E. coli BL21 (DE3) actively produced all target proteins, the concentration of which reached a maximum level as early as $6 \mathrm{~h}$ after IPTG stimulation of the culture. The i-ELISA and immunoblotting results showed that the tested recombinant antigens are recognized by rabbit anti- $B$. abortus $19 \mathrm{WC}$ antibodies, which are evidence of their expression in E. coli cells in an active state.

The chimeric antigens were found to be sufficiently immunogenic, since mice immunized with double injections without using complete Freund's adjuvants showed high levels of antibody titers. An important fact is that antichimeric antibodies also reacted with single proteins, and conversely, murine antibodies to rOmps 19, 25, and/or 31 found their epitopes in chimeric rOmps that prove the authenticity of the fusion proteins.

Anti-Brucella sera obtained from vaccinated, naturally and/or experimentally infected cattle were used to further verify the diagnostic value of the chimeric antigens by i-ELISA. The results testify that fusion protein contains epitopes against which antibodies are produced in vaccinated and infected animals. The antigenicity of rOmps $19+31$ and/or $25+31$ in postvaccinal and post-infectious cattle sera, as well as in rabbit anti-B. abortus $19 \mathrm{WC}$ serum, was more pronounced compared to separately taken single Omps and/or rOmp19+25. However, it is interesting to note that the latter fusion antigen was more immunogenic and, additionally, antibodies against it bind better to its constituent proteins. Apparently, the peptides included in

Table-3: Antigenicity of Brucella chimeric proteins in antisera against the single recombinant outer membrane proteins.

\begin{tabular}{llllll}
\hline \multicolumn{3}{c}{ Mice anti-Brucella sera used in an indirect enzyme-linked immunosorbent assay } \\
\hline \multicolumn{2}{c}{ Antiserum to rOmp19 } & \multicolumn{2}{c}{ Antiserum to rOmp25 } & \multicolumn{1}{c}{ Antiserum to rOmp31 } \\
\hline rOmp19+25 & rOmp19+31 & rOmp19+25 & rOmp25+31 & rOmp19+31 & rOmp25+31 \\
$1: 240$ & $1: 240$ & $1: 400$ & $1: 460$ & $1: 740$ & $1: 460$ \\
$(7.2 \% ;-6.7 \%)$ & $(15.7 \% ;-13.5 \%)$ & $(15.7 \% ;-3.5 \%)$ & $(7.2 \% ;-6.7 \%)$ & $(24.0 \% ;-9.7 \%)$ & $(24.0 \% ;-9.7 \%)$ \\
\hline
\end{tabular}


Table-4: Evaluation of diagnostic values of recombinant outer membrane proteins based i-ELISA compared to RBT.

\begin{tabular}{|c|c|c|c|c|c|c|}
\hline \multirow{2}{*}{$\begin{array}{l}\text { RBT }(+) \\
\text { sera }(n=34)\end{array}$} & \multirow{2}{*}{$\begin{array}{c}\text { RBT (-) sera } \\
\quad(n=43)\end{array}$} & \multicolumn{5}{|c|}{ Characteristics of i-ELISA } \\
\hline & & Antigens & Sensitivity, \% & Specificity, \% & Accuracy, \% & ODt/ODc \\
\hline i-ELISA (+) & i-ELISA (-) & & & & & \\
\hline 30 & 37 & rOmp19 & 88.2 & 86.0 & 87.0 & $4.7 \pm 0.4$ \\
\hline 16 & 40 & rOmp25 & 47.1 & 93.0 & 72.7 & $2.3 \pm 0.1$ \\
\hline 33 & 34 & rOmp31 & 97.1 & 79.1 & 87.0 & $3.0 \pm 0.3$ \\
\hline 34 & 41 & rOmp19+25 & 100 & 95.3 & 97.4 & $4.7 \pm 0.1$ \\
\hline 34 & 42 & rOmp19+31 & 100 & 97.7 & 98.7 & $5.1 \pm 0.1$ \\
\hline 34 & 43 & rOmp25+31 & 100 & 100 & 100 & $2.9 \pm 0.2$ \\
\hline
\end{tabular}

Sensitivity=i-ELISA (+)/RBT (+)×100; Specificity=i-ELISA (-)/RBT (-) $\times 100 ;$ Accuracy=i-ELISA (+) plus ELISA (-)/RBT $(+)$ plus RBT $(-) \times 100 ; \mathrm{ODt}=\mathrm{OD}$ of the test samples; ODC=OD of the control samples, $\mathrm{i}$-ELISA=Indirect enzyme-linked immunosorbent assay, RBT=Rose Bengal test

Table-5: Serological potential of Brucella spp. rOmps.

\begin{tabular}{|c|c|c|c|c|c|}
\hline \multicolumn{6}{|c|}{ Brucella spp. rOmps used as antigens in an indirect enzyme-linked immunosorbent assay } \\
\hline \multicolumn{3}{|c|}{ Individual recombinant proteins } & \multicolumn{3}{|c|}{ Chimeric recombinant proteins } \\
\hline rOmp19 & rOmp25 & rOmp31 & rOmp19+25 & rOmp19+31 & rOmp25+31 \\
\hline \multicolumn{6}{|c|}{ Number of seropositive cows $(n=77)$ from brucellosis-affected farm with anti-rOmps antibodies, heads $(\%)$} \\
\hline $43(55.8)$ & $35(45.5)$ & $46(59.7)$ & $49(63.6)$ & $73(94.8)$ & $76(98.7)$ \\
\hline \multicolumn{6}{|l|}{ ODt/ODc } \\
\hline $3.0 \pm 0.1$ & $3.1 \pm 0.1$ & $2.9 \pm 0.1$ & $2.7 \pm 0.1$ & $4.3 \pm 0.2$ & $3.4 \pm 0.1$ \\
\hline \multicolumn{6}{|c|}{$\begin{array}{l}\text { Number of cattle experimentally infected with Brucella abortus } 544(n=12) \text { with anti-rOmps antibodies on day } 14 \text { post } \\
\text { infection, heads }(\%)\end{array}$} \\
\hline $12(100)$ & $8(66.7)$ & $7(58.3)$ & $12(100)$ & $12(100)$ & $12(100)$ \\
\hline \multicolumn{6}{|l|}{ ODt/ODC } \\
\hline $6.9 \pm 3.0$ & $2.9 \pm 1.8$ & $2.5 \pm 1.9$ & $2.3 \pm 0.4$ & $2.6 \pm 0.5$ & $2.6 \pm 0.5$ \\
\hline
\end{tabular}

rOmps $=$ Recombinant outer membrane proteins

rOmps $19+31$ and $25+31$ are immunogenic only in the structure of the cell wall natural proteins. These results suggest the possibility of creating a chimeric protein that might be a good candidate for diagnostic purposes and the development of subunit vaccines. The protective potential of Brucella fusion proteins consisting of a trigger factor, Omp31 and Bp26 [31], and four major Omps (Omp16, Omp2b, Omp31, and BP26) [32] has been proven in a mouse model. In comparison with single proteins, the use of chimeric antigens yielded higher sensitivity, specificity, and accuracy for detecting anti-Brucella antibodies in cattle serum samples through i-ELISA. The specificity of the assay based on chimeric antigens in testing seropositive animals was slightly lower (by $2 \%-5 \%$ ) than using RBT. It should be noted here that WC used in RBT does not exclude false-positive results due to reactions of heterogeneous serum antibodies with Brucella S-LPS. Thus, the effectiveness of ELISAs based on chimeric proteins should also be determined when compared with that of the bacteriological analysis, that is, the gold standard for brucellosis diagnosis. Further research will be required to fully assess the diagnostic value of the used immunoassay variants and determine their role in the system of bovine brucellosis control in Kazakhstan.

\section{Conclusion}

The accuracy of animal testing for brucellosis is primarily determined by the specificity of the antigens used in the diagnosis of the disease. Serological tests based on Brucella WC and/or LPS could lead to false-positive results due to antigenic similarity of the pathogen to other related bacteria. In this study, we obtained three types of Brucella spp. chimeric antigen, comprising the immunodominant regions of two recombinant proteins: rOmp19+25, rOmp19+31, and rOmp $25+31$. The results showed that chimeric proteins have pronounced immunoreactive properties compared to separately taken single Omps, and might be used to identify infected animals in an unvaccinated herd.

\section{Authors' Contributions}

AKB: Prepared the manuscript and carried out the sample collection. KNM: Designed the study. BKI: Obtained and purified recombinant proteins. ASS: Carried out laboratory analyses. All authors read and approved the final manuscript.

\section{Acknowledgments}

This study was financially supported by the Ministry of Education and Science, Republic of Kazakhstan, within the framework of ScientificTechnical Program (STP) No. BR05236307, and partially supported by the Ministry of Agriculture, Republic of Kazakhstan, during the implementation of STP No. BR10764944.

\section{Competing Interests}

The authors declare that they have no competing interests. 


\section{Publisher's Note}

Veterinary World remains neutral with regard to jurisdictional claims in published institutional affiliation.

\section{References}

1. Franc, K.A., Krecek, R.C., Häsler, B.N. and ArenasGamboa, A.M. (2018) Brucellosis remains a neglected disease in the developing world: A call for interdisciplinary action. BMC Public Health, 18(1): 125.

2. Shome, R., Nagalingam M., Priya, R., Sahay, S., Kalleshamurthy, T., Sharma, A., Bambal, R.G., Rahman, H. and Shome, B.R. (2020) Perceptions and preparedness of veterinarians to combat brucellosis through brucellosis control program in India. Vet. World, 13(2): 222-230.

3. Pappas, G., Papadimitriou, P., Akritidis, N., Christou, L. and Tsianos, E.V. (2006) The new global map of human brucellosis. Lancet Infect. Dis., 6(2): 91-99.

4. Eshmukhametov, A.E., Beisembaev, K.K., Asauova, Z.S. and Sultanova, A.O. (2016) Monitoring and analysis of the epizootic situation of bovine brucellosis in the Republic of Kazakhstan for 2007-2015. Bull. Kostanay State Univ., 2: 36-41.

5. Bonfini, B., Chiarenza, G., Paci, V., Sacchini, F., Salini, R., Vesco, G., Villari, S., Zilli, K. and Tittarelli, M. (2018) Cross reactivity in serological tests for brucellosis: A comparison of immune response of Escherichia coli O157:H7 and Yersinia enterocolitica O: 9 vs Brucella spp. Vet. Ital., 54(2): 107-114.

6. Faria, A.R., Dorneles, E.M.S., Pires, S.D.F., Andrade, H.M.D. and Lage, A.P. (2020) Immunoproteomics of Brucella abortus reveals potential of recombinant antigens for discriminating vaccinated from naturally infected cattle. Microb. Pathog., 147(October): 104345.

7. Belzer, C.A., Tabatabai, L.B. and Deyoe, B. (1991) Differentiation by western blotting of immune responses of cattle vaccinated with Brucella abortus strain 19 or infected experimentally or naturally with virulent Brucella abortus. Vet. Microbiol., 27(1): 79-90.

8. Hoffmann, E.M., Shapiro, S.J. and Nicoletti, P. (1990) Evaluation of serologic and cellular immune responses of cattle to a nonlipopolysaccharide antigen from Brucella abortus. Am. J. Vet. Res., 51(2): 216-221.

9. Cassataro, J., Pasquevich, K., Bruno, L., Wallach, J.C., Carlos, A.F. and Pablo, C.B. (2004) Antibody reactivity to Omp31 from Brucella melitensis in human and animal infections by smooth and rough Brucella. Clin. Diagn. Lab. Immunol., 11(1): 111-114.

10. Gupta, V.K., Verma, D.K., Singh, S.V. and Vihan, V.S. (2007) Serological diagnostic potential of recombinant outer membrane protein (Omp31) from Brucella melitensis in goat and sheep brucellosis. Small Rumin. Res., 70(2-3): 260-266.

11. Bulashev, A.K., Suranshiev, Z.A., Zhumalin, A.K. and Tursunov, K.A. (2016) Antigenicity of Brucella outer membrane proteins. J. Biotechnol. Theory Pract., 1: 20-27.

12. Bulashev, A., Akibekov, O., Suranshiyev, Z.A., Ingirbay, B. and Eskendirova, S. (2019) Serodiagnostic potential of Brucella outer membrane and periplasmic proteins. Turk. J. Vet. Anim. Sci., 43(4): 486-493.

13. Simborio, H.L.T., Lee, J.J., Reyes, A.W.B., Hop, H.T., Arayan, L.T., Min, W., Lee, H.J., Yoo, H.S. and Kim, S. (2015) Evaluation of the combined use of the recombinant Brucella abortus Omp10, Omp19 and Omp28 proteins for the clinical diagnosis of bovine brucellosis. Microb. Pathog., 83(84): 41-46.

14. Ahmed, I., Khairani-Bejo, S., Hassan, L., Bahaman, A. and Omar, A. (2015) Serological diagnostic potential of recombinant outer membrane proteins (rOMPs) from Brucella melitensis in mouse model using indirect enzyme-linked immunosorbent assay. BMC Vet. Res., 11: 275.

15. Bulashev, A., Akibekov, O., Syzdykova, A., Suranshiyev, Z. and Ingirbay, B. (2020) Use of recombinant Brucella outer membrane proteins 19,25 , and 31 for serodiagnosis of bovine brucellosis. Vet. World, 13(7): 1439-1447.

16. Tibor, A., Saman, E., de Wergifosse, P., Cloeckaert, A., Limet, J.N. and Letesson, J.J. (1996) Molecular characterization, occurrence, and immunogenicity in infected sheep and cattle of two minor outer membrane proteins of Brucella abortus. Infect. Immun., 64(1): 100-107.

17. Wergifosse, P., Lintermans, P., Limet, J. and Cloeckaert, A. (1995) Cloning and nucleotide sequence of the gene coding for the major 25-kilodalton outer membrane protein of Brucella abortus. J. Bacteriol., 177(7): 1911-1914.

18. Vizcaino, N., Kittelberger, R., Cloeckaert, A., Marin, C.M. and Fernandez-Lago, L. (2001) Minor nucleotide substitutions in the Omp31 gene of Brucella ovis result in antigenic differences in the major outer membrane protein that it encodes compared to those of the other Brucella species. Infect. Immun., 69(11): 7020-7028.

19. Bulashev, A.K., Tursunov, K.T., Kairova, Z.K. and Syzdykova, A. (2018) Obtaining the strain producing recombinant Brucella abortus Omp19 and studying its antigenicity. Bull. KazATU., 3(98): 117-128.

20. Bulashev, A., Jakubowski, T., Tursunov, K., Kiyan, V. and Zhumalin, A. (2018) Immunogenicity and antigenicity of Brucella recombinant outer membrane proteins. Vet. Med. Zoot., 76(98): 17-24.

21. Erdenebaatar, J., Bayarsaikhan, B., Watarai, M., Makino, S. and Shirahata, T. (2003) Enzyme-linked immunosorbent assay to differentiate the antibody responses of animals infected with Brucella species from those of animals infected with Yersinia enterocolitica O: 9. Clin. Diagn. Lab. Immunol., 10(4): 710-714.

22. Saiduldin, T.S. (1981) Statistical analysis of the results of serological tests. Veterinariya, 7: 62-66.

23. Lim, J.J., Kim, D.H., Lee, J.J., Kim, D.G., Min, W., Lee, H.J., Rhee, M.H., Chang, H.H. and Kim, S. (2012) Evaluation of recombinant $28 \mathrm{kDa}$ outer membrane protein of Brucella abortus for the clinical diagnosis of bovine brucellosis in Korea. J. Vet. Med. Sci., 74(6): 687-691.

24. Vatankhah, M., Beheshti, N., Mirkalantari, S., Khoramabadi, N., Aghababa, H. and Mahdavi, M. (2019) Recombinant Omp2b antigen-based ELISA is an efficient tool for specific serodiagnosis of animal brucellosis. Braz. J. Microbiol., 50(4): 979-984.

25. Kumar, A., Suryawanshi, S.N. and Thavaselvam, D. (2019) Evaluation of diagnostic potential of recombinant outer membrane protein (Romp28) of Brucella melitensis for serodiagnosis of ovine and caprine brucellosis. Defence Life Sci. J., 4(4): 244-249.

26. Yin, D., Li, L., Song, H., Li, H., Wang, J., Ju, W., Qu, X., Song, D., Liu, Y., Meng, X., Cao, H., Song, W., Meng, R., Liu, J., Li, J. and Xu, K. (2016) A novel multi-epitope recombined protein for diagnosis of human brucellosis. BMC Infect. Dis., 16: 219.

27. Nagalingam, M., Basheer, T.J., Balamurugan, V., Shome, R., Kumari, S.S., Reddy, G.B.M., Shome, B.R., Rahman, H., Roy, P., Kingston, J.J. and Gandham, R.K. (2021) Comparative evaluation of the immunodominant proteins of Brucella abortus for the diagnosis of cattle brucellosis. Vet. World, 14(3): 803-812.

28. Navarro-Soto, M., Morales-Loredo, A., Álvarez-Ojeda, G., Ramírez-Pfeiffer, C., Tamez-Guerra, P. and GomezFlores, R. (2015) Recombinant proteins as antigens in serological diagnosis of brucellosis. In: Baddour, M.M., editor. Updates on Brucellosis. Intech Open, Rijeka, Croatia. p161-169.

29. Xu, J., Qiu, Y., Cui, M., Ke, Y., Zhen, Q., Yuan, X., Yu, Y., Du, X., Yuan, J., Song, H., Wang, Z., Gao, G., Yu, S., Wang, Y., Huang, L. and Chen, Z. (2013) Sustained and differential antibody responses to virulence proteins of 
Brucella melitensis during acute and chronic infections in human brucellosis. EJCMID, 32(3): 437-447.

30. Kumar, A., Gupta, V.K., Verma, A.K., Kumar, S.V., Singh, A. and Reddy, N.C.P. (2016) Seroprevalence and risk factors associated with bovine brucellosis in western Uttar Pradesh, India. Ind. J. Anim. Sci., 86(2): 131-135.

31. Karevan, G., Ahmadi, K., Taheri, R.A. and
Fasihi-Ramandi, M. (2021) Immunogenicity of glycine nanoparticles containing a chimeric antigen as Brucella vaccine candidate. Clin. Exp. Vaccine Res., 10(1): 35-43.

32. Yin, D., Bai, Q., Li, L., Xu, K. and Zhang, J. (2021) Study on immunogenicity and antigenicity of a novel Brucella multiepitope recombined protein. Biochem. Biophys. Res. Commun., 540: 37-41.

$* * * * * * * *$ 